\title{
Effect of hot water and ethanol extracts from Nelumbo nucifera Gaertner flower on lipid accumulation and reactive oxygen species (ROS) production in adipogenesis of 3T3-L1 cells
}

\author{
Ji-Won $\mathrm{Oh}^{1}$, Jin-Ha Lee ${ }^{1}, \mathrm{Ok}^{-H w a n} \mathrm{Lee}^{1}, \mathrm{Kye}^{-H o o n} \mathrm{Kim}^{2}, \mathrm{Hey}-\mathrm{Ran} \mathrm{Kim}^{2}$, Hyo-Ku Lee ${ }^{2 *}$ \\ ${ }^{1}$ Department of Food Science and Biotechnology, Kangwon National University, Chuncheon 24341, Korea \\ ${ }^{2}$ Department of Food Science and Technology, Kongju National University, Gongju 32588, Korea
}

\section{T3-L1 세포분화 중 지방축적 및 ROS 생성에 대한 연화 열수 및 에탄올 추출물의 효과}

\author{
오지원 ${ }^{1} \cdot$ 이진하 $^{1} \cdot$ 이옥환 $^{1} \cdot{\text { 김계 }^{2}}^{2} \cdot$ 김혜란 $^{2} \cdot$ 이효구 $^{2 *}$ \\ ${ }^{1}$ 강원대학교 식품생명공학과, ${ }^{2}$ 공주대학교 식품공학과
}

\begin{abstract}
The present study was designed to investigate the effects of hot water and ethanol extracts of Nelumbo nucifera Gaertner flower on lipid accumulation and reactive oxygen species (ROS) production during adipogenesis in 3T3-L1 cells. 3T3-L1 preadipocytes were treated with both hot water and ethanol extracts for up to 8 days following standard induction of differentiation. Regarding anti-adipogenic activity, compared with the control, the hot water and ethanol extracts significantly inhibited lipid accumulation (37.4 and $66.6 \%$, respectively) and ROS production (46.4 and $46.8 \%$, respectively) during adipogenesis in 3T3-L1 cells. Treatment with hot water and ethanol extracts significantly inhibited mRNA expression of peroxisome proliferator-activated receptor gamma (PPARy) and CCAAT/ enhancer-binding protein alpha (C/EBPa), thereby reducing the mRNA expression of adipocyte-specific fatty acid binding protein (aP2). Moreover, both the extracts significantly inhibited mRNA expression of NADPH oxidase (NOX4). Overall, our research suggests that $N$. nucifera Gaertner flower extracts might be a valuable source of bioactive compounds that exhibit anti-adipogenic activity and could have applications in the field of medicine and food industry.
\end{abstract}

Key words : Nelumbo nucifera Gaertner, extracts, 3T3-L1 cell, lipid accumulation, reactive oxygen species

\section{서 론}

연화(lotus flower)는 연꽃(Nelumbo nucifera Gaertner)의 꽃봉우리로서 수련과의 여러살이해 수상식물이며 East Indian lotus 및 Chinese water lily라고도 불리운다(1). 연꽃 의 씨앗은 연자육(Nelumbinis Semen)이라하며, 연꽃의 뿌리 는 연근(lotus root, Nelumbinis Rhizoma)으로 식품원재료

*Corresponding author. E-mail : hhklee@kongju.ac.kr Phone : 82-41-330-1482, Fax : 82-41-330-1489

Received 8 September 2015; Revised 24 September 2015; Accepted 25 September 2015.

Copyright (c) The Korean Society of Food Preservation. All rights reserved.
데이터베이스에 식품원료로 사용가능하다고 분류되어 있 으며, 연잎, 연화 등도 건강식품의 원료로 사용되고 있다 $(1,2)$. 최근에 보고된 연꽃에 관한 연구로 연화 및 연화주의 영양성분 및 항산화활성(3), 국내 재배 연근과 연자육의 항비만과 항산화 효과(4), 6 가 크롬으로 유도된 세포독성에 대한 연꽃 추출물의 보호효과(5), 과산화수소로 손상된 배 양 인체피부흑색종세포에 대한 연꽃수술추출물의 항산화 효과 및 멜라닌화 방어효과(2), 활성산소종인 glucose oxidase로 손상된 배양 C6 Glioma 세포에 미치는 항산화효 과(6), tyrosinase 활성억제 및 멜라닌 생성억제에 의한 미백 효과(1), UVB 자외선 조사에 의한 각질형성세포의 보호 및 피부 노화방지(7) 등이 보고되었다. 연꽃에 함유된 주요 flavonoid 성분으로는 quercetin, luteolin, isoquercitrin, 
luteolin glucoside, kaepferol-3-diglucoside등이 알려져 있다 (8-10).

서구화된 식습관과 생활습관의 변화로 에너지 불균형에 의한 체내 중성지방의 축적은 비만(obesity)을 야기하며 비 만으로 인한 인슐린 저항성, 이상지혈증 등의 만성질환의 유발은 급속하게 증가되고 있다 $(11,12)$. 체내 지방의 축적 은 조직내 지방세포(adipocytes)의 비대(hypertrophy)와 과 형성(hyperplasia)으로 진행되며 분화된 세포 내의 활성화 된 지방질 생합성(lipogenesis) 작용에 의하여 생성된 지방 구 축적에 의하여 유도된다. 또한, 지방세포 과형성은 전지 방세포(preadipocytes)의 활발한 증식과 활성화된 지방세포 분화 과정으로 인하여 유도되기 때문에 지방세포의 분화 (adipogenesis)는 지방세포의 과형성 뿐만 아니라 hypertrophy capacity 결정에 중요한 요소로서 adipogenesis를 억제하는 것은 비만에 있어서 효율적인 타깃으로 연구되고 있다 (13-17). 지방세포 분화과정에서 활성산소종(reactive oxygen species, ROS)의 과도한 생성은 세포내 산화적 스트레스를 유발하게 되며 이로 인하여 단백질 변성, 지질과산화물 생 성, DNA 변이를 일으켜 노화와 암을 유발시키는 주요원인 이 되기도 한다 $(18,19)$.

최근 천연물을 이용한 지방세포 분화억제 및 ROS 저감 에 대한 연구가 활발히 이루어지고 있는 시점에서, 연화에 대한 연구는 초기단계에 머물러 있다. 따라서 본 연구는 3T3-L1 전지방세포의 세포분화 과정에서 지방축적 및 ROS 생성에 미치는 연화 열수 및 에탄올 추출물의 효과를 관찰 하고자 하였다. 연화 추출물에 의한 지방세포 분화단계에 서의 주요 전사인자(adipogenic transcription factors), $\mathrm{NADPH}$ 산화효소 4(NAPDH oxidase 4, ROS 생성 유전자) 및 catalase(항산화효소)들의 발현 정도를 조사하였다.

\section{재료 및 방법}

\section{실험재료 및 시약}

본 연구에 사용된 연화는 2014년에 수확한 것으로 경북 칠곡의 영농조합법인 석전상온전통주가에서 제공받아 사 용하였다. 전지방세포(3T3-L1) 배양 및 분화에 사용된 시약 으로 penicillin-streptomycin(P/S), insulin, dexamethasone (DEX), 3-isobutyl-1-methylxanthine(IBMX), nitroblue tetrazolium (NBT), Oil Red O(ORO), isopropyl alcohol, N-Acetyl-Lcysteine(NAC)은 Sigma(Sigma-Aldrich Co., St. Louis, MO, USA)에서 구입하여 사용하였다. Dulbecco's modified Eagle's medium(DMEM), fetal bovine serum(FBS), bovine serum(BS), phosphate-buffered saline(PBS) 및 trypsin-EDTA 등은 Gibco(Gaithersburg, MD, USA)로부터 구입하여 사용 하였다.

\section{열수 및 에탄올 추출물의 제조}

연화 열수 및 에탄올 추출물을 제조하여 지방세포 분화 억제 효능평가를 실시하였다. 세척하여 이물을 제거한 연 화를 동결건조(FD5508, Ilshinbiobase Co., Ltd., Gyeonggi, Korea) 한 후, 조분쇄하여 20 30 mesh로 분말화 하였다. 분말화된 연화 $50 \mathrm{~g}$ 에 약 20 배의 증류수 및 $80 \%$ 에탄올을 각각 첨가하고 $80 \sim 100^{\circ} \mathrm{C}$ 수욕 상에서 3시간동안 환류냉각 하면서 3회 반복 추출하였다. 각각의 조추출물은 Whatman filter paper No. 3(Whatman Ltd., Maidstone, Kent, UK)를 이용하여 여과 한 뒤 $4^{\circ} \mathrm{C}$ 에서 방냉한 후, 동일 여과지로 재여과하여 $50^{\circ} \mathrm{C}$ 에서 감압농축(N-1200A, Tokyo Rikakikai Co., Ltd., Tokyo, Japan) 한 후 동결건조 하여 연화 열수 추출물 및 $80 \%$ 에탄올 추출물을 제조하였다.

\section{T3-L1 세포 배양 및 분화}

3T3-L1 세포는 American Type Culture Collection(ATCC, CL-173, Manassas, VA, USA)으로부터 분양 받아 사용하였 다. 3T3-L1 전지방세포는 실험목적에 따라 $100 \Phi, 24-w e l l$ 및 96-well plate에 각각 $1 \times 10^{6}$ cells/well을 seeding한 후, $\mathrm{BS}(10 \%)$ 및 $\mathrm{P} / \mathrm{S}(1 \%)$ 를 함유한 고농도 포도당 $\mathrm{DMEM}(89 \%)$ 에서 $100 \%$ confluence 될 때까지 배양하였다. 이로부터 2 일 후에, 지방세포 분화유도 물질 $(10 \mu \mathrm{g} / \mathrm{mL}$ insulin, $1 \mu \mathrm{M} \mathrm{DEX}$, $0.5 \mathrm{mM} \mathrm{IBMX})$ 과 $\mathrm{FBS}(10 \%)$ 및 $\mathrm{P} / \mathrm{S}(10 \%)$ 를 함유한 $\mathrm{DMEM}$ 으로 전지방세포를 지방세포로 분화유도 하였다. 지방세포 분화(day 0)시 DMEM에 시료를 각각 $400 \mu \mathrm{g} / \mathrm{mL}$ 로 처리하 였고, 양성 대조군(positive control)에는 항산화제인 NAC를 처리하여 비교하였다. 지방세포의 분화는 분화유도 물질을 처리한 후, 2 일마다 지속적으로 $10 \mathrm{\mu g} / \mathrm{mL}$ insulin, $1 \% \mathrm{P} / \mathrm{S}$, $10 \% \mathrm{FBS}$ 가 함유된 배지에 각각의 시료를 처리한 후, 8 일 동안 분화시키면서 지방축적량 및 $\mathrm{ROS}$ 의 생성량을 관찰하 였다.

\section{XTT assay를 이용한 세포독성평가}

3T3-L1 세포에 대한 연화 열수 및 에탄올 추출물의 세포 독성평가는 XTT\{2,3-bis(2-methoxy-4-nitro-5-sulfophenyl)2H-tetrazolium-5-carboxanilide innersalt $\}$ assay kit를 이용하 여 측정하였다.

\section{Oil red $O$ staining을 이용한 지방축적량 관찰}

분화 과정에 따른 3T3-L1 세포 내 지방축적량을 측정하 고자 각각의 시료를 처리하여 24-well에서 8일 동안 분화된 3T3-L1 세포의 배양액을 제거한 후, $10 \%$ formalin 용액 500 $\mu \mathrm{L}$ 를 첨가하여 5 분간 실온에서 방치한 뒤 제거하였다. 그 후 동량의 formalin 용액으로 분화된 3T3-L1 세포 1시간 이상 실온에서 방치한 후, formalin을 제거하고 $60 \%$ isopropyl alcohol 용액 $500 \mu \mathrm{L}$ 로 세척하여 세포를 완전히 건조시켰다. 완전히 건조된 세포들은 미리 제조해 둔 Oil 
red O working solution(Oil red O : DDW = 6:4)으로 세포 내 축적된 지방성분들을 충분히 염색 한 후, 증류수를 이용 하여 세포를 3 4회 세척하고 완전히 건조시켰다. 세포 내 축적된 지방 성분과 결합한 Oil red O는 $100 \%$ isopropyl alcohol을 이용하여 모두 용출 시킨 후, microplate reader를 이용하여 $490 \mathrm{~nm}$ 에서 흡광도를 측정하였다.

\section{NBT assay를 이용한 ROS 함량 측정}

분화과정에 따른 지방세포의 ROS 생성량을 측정하기 위하여 먼저 24-well에 배양 및 분화된 3T3-L1 세포의 배양 액을 제거한 후 멸균된 $\mathrm{PBS}(\mathrm{pH}$ 7.4)를 이용하여 2회 세척, $0.2 \% \mathrm{NBT}$ 용액 $0.2 \mathrm{~mL}$ 를 첨가하여 $\mathrm{CO}_{2}$ incubator안에서 90 분간 반응시킨 뒤 $\mathrm{DMSO}$ 와 $1 \mathrm{~N} \mathrm{KOH}$ 를 7:3 혼합한 용액 을 이용하여 이들 dark blue formazan을 모두 용출시켜 microplate reader를 이용하여 $570 \mathrm{~nm}$ 에서 흡광도를 측정하 였다.

지방축적 및 ROS 생성과 연관된 주요 유전자의 발현 조사 지방세포 분화에 영향을 미치는 주요 관련 유전자들의 발현 정도 변화를 검토하기 위하여 지방세포에 존재하는 total RNA를 추출한 후, 역전사중합효소(reverse transcriptase) 를 사용하여 complementary DNA(cDNA)를 만들고 합성된 cDNA와 primer로 RT-PCR을 이용하여 유전자의 발현 정도 를 측정하였다. 실험에 사용한 유전자는 GAPDH(Forward; CAAGGTCATCCATGACAACTTTG, GGCCATCCACAG TCTTCTGG), PPAR 8 (Forward; CCAGAGTCTGCTGATC TGCG, Reverse; GCCACCTCTTTGCTCTGATC), C/EBPa (Forward; GCAGTGTGCACGTCTATGCT, Reverse; AGCC
CACTTCATTTCATTGG), aP2(Forward; GACCTGGAAA CTCGTCTCCA, Reverse; CATGACACATTCCACCACCA), NOX4(Forward; GAAGCCCATTTGAGGAGTCA, Reverse; GGGTCCACAGCAGAAAACTC), catalase(Forward; TCTG CAGATACCTGTGAACTG, Reverse; TAGTCAGGGTGG ACGTCAGTG) 이었다. RT-PCR 산물은 $1.5 \%$ 한천 (agarose) 겔에서 전기영동 후 자외선투시기를 이용하여 증 폭된 DNA band를 확인하였다. DNA band는 Carestream MI SE(Carestream Health Inc., Rochester, NY, USA) 프로그

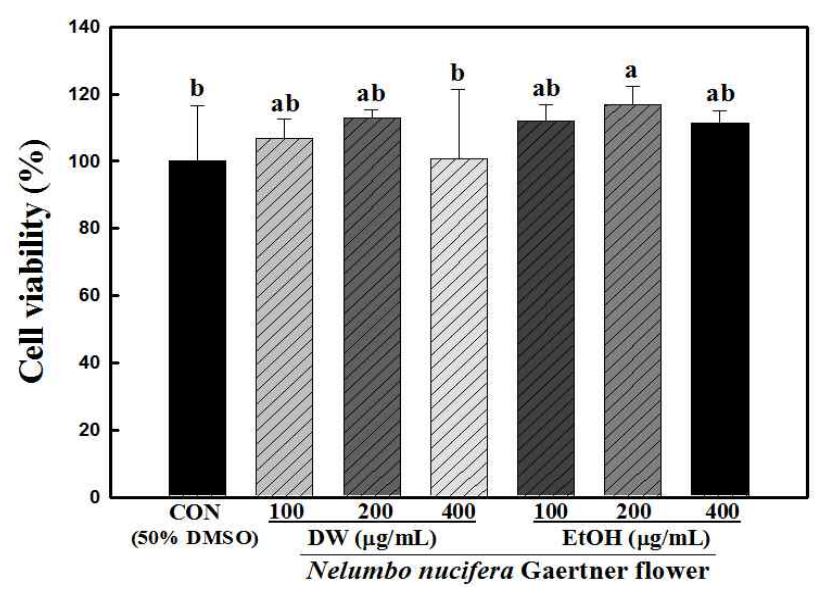

Fig. 1. Effects of hot water and ethanol extracts of Nelumbo nucifera Gaertner flower on cell viability.

Cell viability was measured by XTT assay. The exponentially growing cells were plated into 96-well plates at a density of $1 \times 10^{6}$ cells/well in DMEM/BS medium and incubated for $24 \mathrm{hr}$ prior to treatment at $37^{\circ} \mathrm{C}$ in $5 \% \mathrm{CO}_{2}$. Cells were divided into a control group and a treatment groups. Each value is the mean $t$ standard deviation $(\mathrm{n}=6)$ and is representative of results from at least two different experiments. Statistical analysis was performed using the one-way ANOVA $(\mathrm{p}<0.05)$.
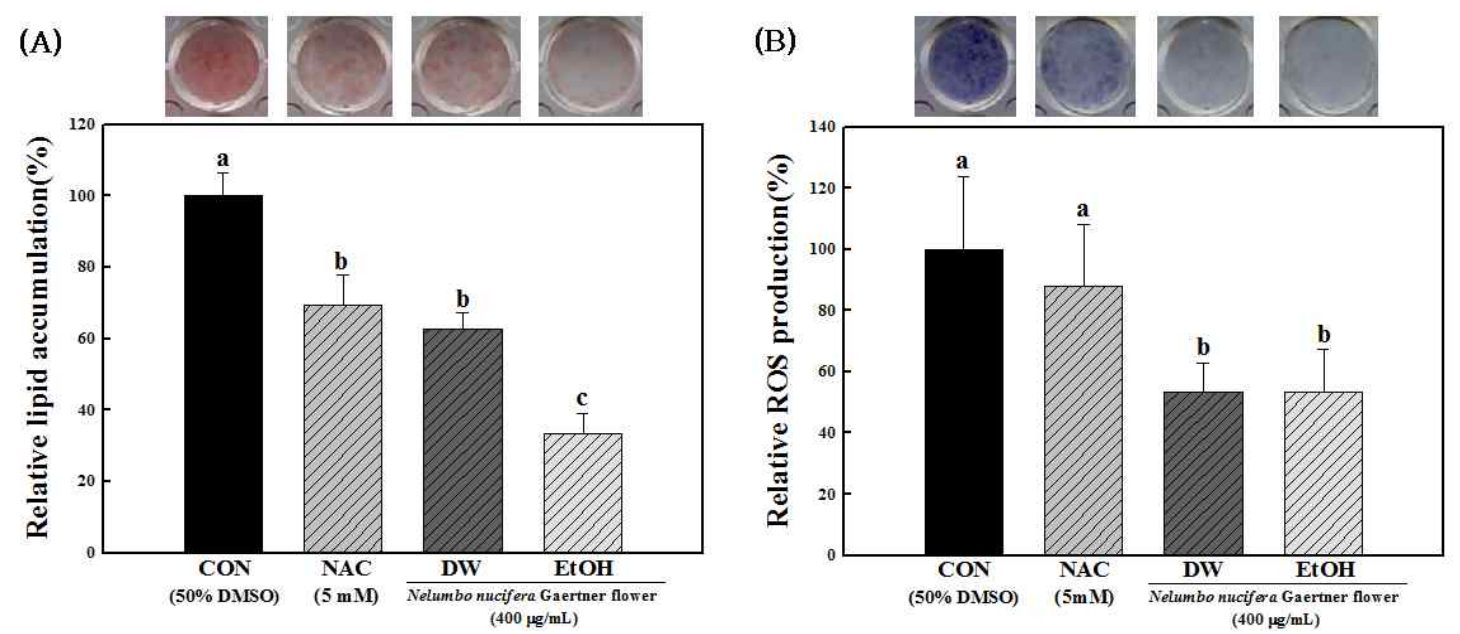

Fig. 2. Hot water and ethanol extracts of Nelumbo nucifera Gaertner flower inhibit adipose conversion and ROS production during differentiation of 3T3-L1 preadipocytes.

(A) Oil red 0 staining and NBT assay at day 8 with or without Nelumbo nucifera Gaertner flower extracts. (B) ROS production during differentiation of 3T3-L1 cells into adipocytes. Each value is the mean \pm standard deviation $(\mathrm{n}=6)$ and is representative of results from at least two different experiments. Statistical analysis was performed using the one-way ANOVA $(\mathrm{p}<0.05)$. 
램을 이용하여 band intensity로 수치화하여 나타내었다.

\section{통계분석}

모든 실험결과는 $\operatorname{SAS}(9.4$, SAS Institute Inc., Cary, NC, USA)를 이용하여 통계분석 하였다. 유의성 분석은 ANOVA 검정을 실시하였으며 Duncan의 다중범위 검정법 (Duncan's multiple range test)으로 유의성은 $\mathrm{p}<0.05$ 수준에 서 검정하였다.

\section{결과 및 고찰}

3T3-L1 분화과정 중 연화 추출물들의 지방축적 저감효과

연화 열수 및 에탄올 추출물은 100,200 및 $400 \mathrm{\mu g} / \mathrm{mL}$ 의 농도에서 세포 독성을 나타내지 않았으며, 현미경 상에서 의 morphology의 변화도 관찰되지 않았다(Fig. 1). 3T3-L1 세포분화 억제 효과를 확인하기 위하여 중성지방만을 붉은 색으로 염색하는 Oil red O 염색법을 통해 3T3-L1 지방세포 내 생성된 중성지방의 양을 측정한 결과는 Fig. 2(A)와 같다.
연화 열수 및 에탄올 추출물을 처리하지 않은 대조군에비하 여 연화 열수 및 에탄올 추출물을 각각 $400 \mathrm{\mu g} / \mathrm{mL}$ 처리한 군에서 지방축적량은 유의적으로 감소하는 경향을 보였으 며, 열수 추출물에 비해 에탄올 추출물에서 지방세포 분화 억제 효능이 높게 나타났다. 이러한 결과는 Kwak 등(3)과 Lee 등(20)의 연구에서 연화 열수 및 에탄올 추출물에 함유 된 총 페놀(69.7 76.0 mg GAE/g) 및 총 플라보노이드(20.1 $\sim 21.9 \mathrm{mg} \mathrm{QE} / \mathrm{g}$ ) 화합물이 항산화활성 등의 생리활성을 나타낸다는 실험결과와 유사한 경향을 보였다. 지방세포의 분화 및 지방축적과 연관된 주요 전사인자로 알려진 PPAR $\mathrm{\gamma}, \mathrm{C} / \mathrm{EBPa}$ 및 $\mathrm{aP} 2$ 의 발현에서도 Fig. 3에서와 같이 연화 열수 및 에탄올 추출물 처리군이 대조군에 비해서 각각 유의적으로 감소하는 경향을 나타내었다. 이들 유전자의 발현은 지방세포의 분화정도를 측정할 수 있는 대표적인 전사인자들로 연화 열수 및 에탄올 추출물을 처리하지 않은 대조군에 비하여 연화 열수 및 에탄올 추출물을 각각 400 $\mu \mathrm{g} / \mathrm{mL}$ 처리한 군에서 유의적으로 감소시키는 것을 확인할 수 있었다. 지방조직에서 주로 나타나는 PPAR8, C/EBPa 및 $\mathrm{aP2}$ 는 발현이 증가할수록 세포의 전지방세포에서 지
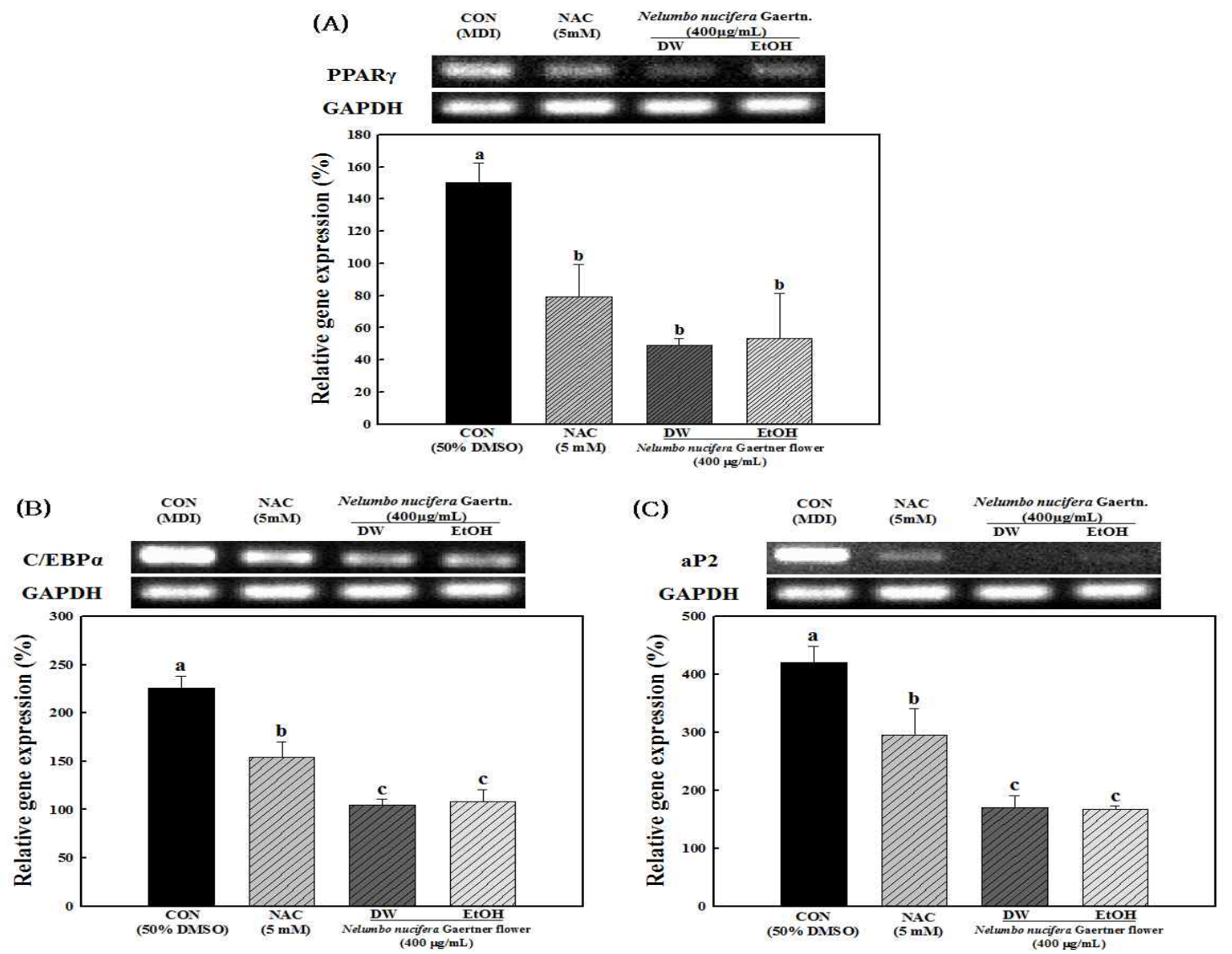

Fig. 3. Effects of hot water and ethanol extracts of Nelumbo nucifera Gaertner flower on mRNA expression of adipogenic transcription factors during adipogenesis in 3T3-L1 preadipocytes.

Total cellular RNA was extracted and subjected to RT-PCR. PPARz (A), C/EBPa (B) and aP2 (C) mRNA levels were quantified and normalized with to GAPDH. Each values are the mean \pm standard deviation of the samples. Bars with different letters indicate statistically significant differences among groups at $p<0.05$ by one-way ANOVA. 
방세포로의 분화를 크게 증가시키는 것으로 알려져 있는데 3T3-L1 세포의 분화시 연화 열수 및 에탄올 추출물의 처리 에 따른 지방생성 억제 효과는 PPARy, C/EBPa 및 $\mathrm{aP2}$ 의 발현과 크게 관련이 있다고 판단되어 진다 $(21,22)$. 실험에 사용된 NAC는 대표적인 항산화제로 3T3-L1의 분화과정 중 처리하면 중성지방의 축적을 억제시키고, 또한 지방세 포의 분화를 조절하는 전사인자인 PPARy와 $\mathrm{C} / \mathrm{EBP} \beta$ 의 발 현을 억제하는 것으로 알려져 있어 양성 대조군으로 사용하 였다(23). 이 결과를 통해 연화 열수 및 에탄올 추출물이 3T3-L1 지방세포 내 중성지방의 생성 및 축적 억제효과가 큰 것으로 나타났다.

\section{T3-L1 분화과정 중 연화 열수 및 에탄올 추출물에 의한 $\mathrm{ROS}$ 생성 억제 효과}

NBT assay는 NBT 용액이 지방세포 내에 축적된 ROS과 반응하여 dark blue formazan을 생성하게 되며, 이를 용출하 여 세포 내 ROS의 생성랑을 알 수 있다. 3T3-L1 전지방세포 에 분화 유도 물질을 처리하여 지방세포로 분화 시킨 뒤 생성된 ROS 생성량을 측정하기 위하여 NBT assay를 이용 하여 측정한 결과는 Fig. 2(B)와 같다. 연화 열수 및 에탄올 추출물을 처리하지 않은 대조군에 비하여 연화 열수 및 에탄올 추출물을 각각 $400 \mathrm{\mu g} / \mathrm{mL}$ 처리한 군에서 ROS 생성 량이 유의적으로 감소하는 것으로 나타났다. NOX4 (NADPH oxidase 4)는 지방세포 내 대사과정에서 생성되는 $\mathrm{NADPH}$ 에 의하여 ROS를 생성하는 단백질로 지방세포에 서만 특이적으로 발현된다. 지방세포의 분화과정에서 NOX4에 의하여 생성된 superoxide는 지방세포의 주요 활성산소종으로 알려져 있다 $(24,25)$. Catalase는 세포내
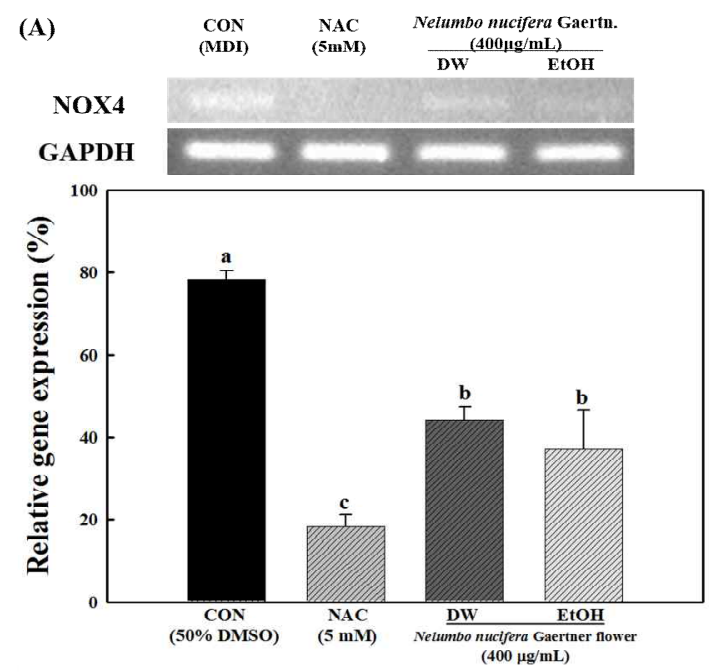

hydrogen peroxide $\left(\mathrm{H}_{2} \mathrm{O}_{2}\right)$ 를 유의적으로 소거하여 ROS에 대 항하는 중요한 항산화효소로서 일반적인 물질대사 과정 동안에 발생한 $\mathrm{H}_{2} \mathrm{O}_{2}$ 를 $\mathrm{H}_{2} \mathrm{O}$ 와 $\mathrm{O}_{2}$ 로 변환시키는 역할을 하 는 것으로 알려져 있다(26). Fig. 4는 연화 열수 및 에탄올 추출물에 의한 지방세포 내 NOX4 및 catalase의 유전자 발현을 나타낸 것으로 연화 열수 및 에탄올 추출물을 처리 하지 않은 대조군에 비하여 연화 열수 및 에탄올 추출물을 각각 $400 \mathrm{\mu g} / \mathrm{mL}$ 처리한 군에서 NOX4의 발현량이 유의적 으로 감소하는 것으로 나타났으며 항산화효소인 catalase의 발현량이 유의적으로 증가하는 것으로 나타났다. Yang 등 (27)과 Lee 등(28)에 의하면 연화에는 quercetin, kaempferol 등 플라보노이드 계열의 성분이 함유되어 있는 것으로 보고 되어 이와 같은 효능은 연화에 함유된 플라보노이드 계열 성분에 기인한 것으로 사료된다. 양성 대조군으로 사용된 $\mathrm{NAC}$ 는 3T3-L1의 분화과정 중 ROS의 생성을 억제하며, 글루타치온(glutathione)의 전구체로써 세포 내 항산화 효소 의 생성에 도움을 주는 것으로 보고되고 있다(29).

위 결과를 통하여 연화 열수 및 에탄올 추출물은 지방세 포 내의 중성지방의 축적 및 ROS 생성을 억제하여 비만과 산화적 스트레스에 효과를 갖는 천연 소재임을 알 수 있었다.

\section{요 약}

본 연구에서는 연화 열수 및 에탄올 추출물의 3T3-L1 지방세포 분화 및 ROS생성 저감효과를 구명하기 위하여 3T3-L1 전지방세포 분화과정 중 연화 열수 및 에탄올 추출 물에 의한 지방축적과 ROS 생성을 관찰하였다. 연화 열수
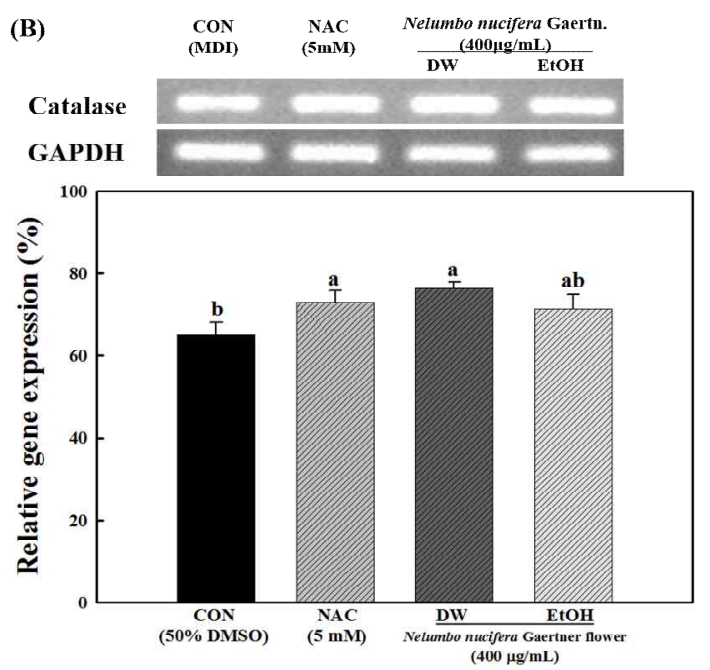

Fig. 4. Effects of hot water and ethanol extracts of Nelumbo nucifera Gaertner flower on mRNA expression of NOX4 (A) and catalase (B) during adipogenesis in 3T3-L1 preadipocytes.

CON, control (MDI) NAC, N-acetyl cysteine. Total cellular RNA was extracted and subjected to RT-PCR. NOX4 and catalase mRNA levels were quantified and normalized with to GAPDH. Each values are the meantstandard deviation of samples. Bars with different letters indicate statistically significant differences among groups at $p<0.05$ by one-way ANOVA. 
및 에탄올 추출물은 XTT assay에서 100, 200 및 $400 \mu \mathrm{g} / \mathrm{mL}$ 농도에서 세포 독성을 보이지 않았다. 지방세포 분화 중 세포 내 지방축적 및 $\operatorname{ROS}$ 생성량을 비교한 결과, 연화 열수 및 에탄올 추출물을 처리한 지방세포의 경우 지방축적량과 ROS 생성량 모두 유의적으로 억제되는 것으로 나타났다. 특히 연화 열수 및 에탄올 추출물을 처리함으로써 지방세포 분화와 관련된 전사인자인 PPARy, C/EBPa 및 $\mathrm{aP} \mathrm{mRNA}$ 의 발현을 유의적으로 감소시켰으며, ROS의 생성과 관련이 있는 주요 유전자인 NOX4 및 catalase의 유전자발현 또한 유의적으로 감소하였다. 이 결과를 통해 연화 열수 및 에탄 올 추출물이 3T3-L1 지방세포 내 중성지방의 축적 억제 효과와 더불어 ROS 생성 억제에 효과적으로 작용함을 확인 하였다. 따라서 연화 열수 및 에탄올 추출물은 비만과 같은 대사증후군 관련 질환의 개선을 위한 천연물 기능성 소재로 의 활용이 기대된다.

\section{감사의 글}

본 연구는 2015년도 공주대학교 학술연구비 지원에 의하 여 수행되었으며, 이에 감사드립니다.

\section{References}

1. Chang MS, Kim HM, Yang WM, Kim DR, Park EH, Ko EB, Choi MJ, Kim HY, Oh JH, Shim KJ, Yoon JW, Park SK (2007) Inhibitory effects of Nelumbo nucifera on tyrosinase activity and melanogenesis in Clone M-3 melanocyte cells. Korean J Herbol, 22, 87-94

2. Kim MS, Park YJ, Sohn YW (2010) Antioxidative effect and melanogenesis of Nelumbo nucifera stamen extract on cultured Human skin melanoma cells injured by hydrogen peroxide. Korean J Plant Res, 23, 145-150

3. Kwak WS, Lee SK, Lee KJ, Kim KH, Kim HR, Lee HK, Oh JW, Lee OH (2014) Nutritional components and antioxidant activities of Nelumbo nucifera Gaertner flower and its wine. Korean J Food Preserv, 21, 373-380

4. Yoo JS (2014) Antioxidant and antiobesity effects of lotus (Nelumbo nucifera) root and seed grown in Korea. $\mathrm{PhD}$ Thesis. Inha University, Incheon, Korea, p 5-11

5. Seo YM, Park YJ, Choi YS (2009) Study on the protective effect of Nelumbo nucifera GAERTN extract on cultured cerebral neuroglial cells damaged by hexavalent chromium. Flower Res J, 17, 242-245

6. Oh YL (2010) Effect of flower extract on antioxidative of cultured C6 glioma cells damaged by glucose oxidase of reactive oxygen species in Nelumbo nucifera. J Korean Soc People Plants Environ, 13, 17-24

7. Chang MS, Ko EB, Lee HJ, Kim JS, Kim JS, Jee SW, Kim HY, Yeom MH, Kim DH, Kim HK, Park SK (2011) The effects of Nelumbo nucifera on utraviolet-B irradiated human keratinocytes. Korean J Herbol, 26, 45-49

8. Lee KS, Kim MG, Lee KY (2006) Antioxidative activity of ethanol extract from lotus (Nelumbo nucifera) leaf. J Korean Soc Food Sci Nutr, 35, 182-186

9. Park SY, Hwang TY, Kim JH, Moon KD (2001) Quality changes of minimally processed lotus root (Nelumbo nucifera) with browning inhibitors. Korean J Postharvest Sci Technol, 8, 164-168

10. Peng Q, Wei Z, Lau BH (1998) Fructus corni enhances endotherial cell antioxidant defenses. Gen Pharmacol, 31, 221-225

11. Spiegelman BM, Flier JS (2001) Obesity and the regulation of energy balance. Cell, 104, 531-543

12. Marcelin G, Chua S (2010) Contributions of adipocyte lipid metabolism to body fat content and implications for the treatment of obesity. Curr Opin Pharmacol, 10, 588-593

13. Holst D, Grimaldi PA (2002) New factors in the regulation of adipose differentiation and metabolism. Curr Opin Lipidol, 13, 241-245

14. de Ferranti S, Mozaffarian D (2008) The perfect storm : obesity, adipocyte dysfunction, and metabolic consequences. Clin Chem, 54, 945-955

15. Attie AD, Scherer PE (2009) Adipocyte metabolism and obesity. J Lipid Res, 50, 395-359

16. Rosen ED, MacDougald OA (2006) Adipocyte differentiation from the inside out. Nat Rev Mol Cell Biol, 7, 885-896

17. Kim KH (2009) Perspective in regulation of adipogenesis by bioactive food components. Food Sci Ind, 42, 51-57

18. Lee OH, Kwon YI, Hong HD, Park CS, Lee BY, Kim YC (2009) Production of reactive oxygen species and changes in antioxidant enzyme activites during differentiation of 3T3-L1 adipocyte. J Korean Soc Appl Biol Chem, 52, 70-75

19. Valko M, Moncol DJ, Cronin TD, Mazura M, Telser J (2007) Free radicals and antioxidants in normal physiological functions and human disease. Int J Biochem Cell Biol, 39, 44-84

20. Lee JY, Yu MR, An BJ (2010) Comparison of biological activity between Nelumbo nucifera G. extracts and 
comsmetics adding Nelumbo nucifera G.. J Life Sci, 20, 1241-1248

21. Rosen ED (2005) The transcriptional basis of adipocyte development. Prostaglandins Leukot Essent Fatty Acid, 73, 31-34

22. Evans RM, Barish GD, Wang YX (2004) PPARs and the complex journey to obesity. Nat Med, 10, 355-361

23. Pablo C, Daiana S, Soledad C, Virginia D, Lelia D, Juan CC, Liliana NG (2011) N-Acetylcysteine reduces markers of differentiation in 3T3-L1 adipocytes. Int J Mol Sci, 12, 6936-6951

24. Sampson N, Koziel R, Zenzmaier C, Bubendorf L, Plas E, Jansen-Dürr P, Berger P (2011) ROS signaling by NOX4 drives fibroblast-to-myofibroblast differentiation in the diseased prostatic stroma. Mol Endocrinol, 25, 503-515

25. Basuroy S, Tcheranova D, Bhattacharya S, Leffler CW, Parfenova H (2011) Nox4 NADPH oxidase-derived reactive oxygen species, via endogenous carbon monoxide, promote survival of brain endothelial cells during TNF-a-induced apoptosis. Am J Physiol Cell
Physiol, 300, C256-265

26. Chance B, Oshino N (1971) Kinetics and mechanism of catalase in peroxisomes of the mitochondrial fraction. Biochem J, 112, 225-233

27. Yang RZ, Wei XL, Gao FF, Wang LS, Zhang HJ, Xu YJ, Li CH, Ge YX, Zhang JJ, Zhang J (2009) Simultaneous analysis of anthocyanins and flavonols in petals of lotus (Nelumbo) cultivars by high-performance liquid chromatography-photodiode array detection/electrospray ionization mass spectrometry. J Chromatogr A, 1216, 106-112

28. Lee JJ, Park SY, Lee MY (2006) Effect of lotus root (Nelumbo nucifera G.) on lipid metabolism in rats with diet-induced hypercholesterolemia. Korean J Food Preserv, 13, 634-642

29. Furukawa S, Fujita T, Shimabukuro M, Iwaki M, Yamada Y, Nakajima Y, Nakayama O, Makishima M, Matsuda M, Shimomura I (2004) Increased oxidative stress in obesity and its impact on metabolic syndrome. J Clin Invest, 114, 1752-1761 